\title{
ENCOUNTERING RECENT AFRICAN MIGRANTS AND IMMIGRANTS TO SOUTH AFRICA: Towards understanding the role of religion and culture in the reception of recent African migrants and immigrants to South Africa
}

\author{
Hans P Müller \\ University of Stellenbosch
}

\begin{abstract}
:
A very public debate and some street confrontations show that many South Africans find it difficult to come to terms with the idea that Africans from outside South Africa live and work in South Africa. Contrary to a dominant discourse using religion and culture as resources for the positing of unity, recognition and reconciliation, xenophobia seems to have become part of the South African landscape. However, the reasons for the xenophobia are more complex than expected. Most of the negative perceptions of South Africans about foreign Africans in South Africa have proved to be false. The possibility of religious and cultural constructions mediating the xenophobia is explored. It is argued that an entry into the problem through religion and culture should contribute to a better understanding of the problem, but hat too little empirical work has been done in this respect to date.
\end{abstract}

\section{The current situation}

The reception of non-South African immigrants and migrants to South Africa has recently been the subject of emotional public debate. It has also been the stuff of violent confrontation. In a country where life is often cheap, migrants and foreigners also have their place in the statistics. However, sometimes they are targets not because they have something of value or because they happen to be in the wrong place at the wrong time but because they are foreign. A recent example was reported as follows: 'Three foreigners, two from Senegal and one from Mozambique, were killed on a train near Pretoria... after a mob accused them of stealing jobs from South Africans. Two of the victims were electrocuted by overhead wires when they tried to escape... The third man was run over by an oncoming train after he was pushed out of a window' (Cape Times 04/09/1998).

Africans who are not South Africans are sometimes regarded as competition that may legitimately be expunged or at least abused. The accusations underlining this kind of opinion, range from 'stealing' South African women, to occupying prime hawking space, to taking up jobs that should have gone to South Africans, to tapping into social welfare that should have gone to South Africans ${ }^{1}$. In the process, a collective and derogatory name for foreign Africans (makwerekwere), has come to be applied regularly - with the exception of those from Lesotho, Botswana and Swaziland. Vigilantes from particular townships have sometimes tried to evict, forcefully and systematically, all those taken to be non-South African (Human Rights Watch 1998:135-136).

1. The service provided by the Southern African Migration Project (run by IDASA and a Canadian team from Queen's University) collects news items in South African newspapers relating to migrants. This can be found at http://www.queensu.ca/samp/news 
Historically, South Africa has been part of a web of migration long before this century. However, in $20^{\text {th }}$ century history ${ }^{2}$, the most important facet has been the employment of migrant workers in the mining industry and to a lesser extent in agriculture (Wilson \& Ramphele 1989:196-201; Crush, Jeeves \& Yudelman 1991). Since the discovery of gold and diamonds, miners from Mozambique, Lesotho, Swaziland, Botswana, Zimbabwe, Malawi, Zambia and even Angola have gone down the shafts and worked the stopes of South African mines. The story of these people goes on to this day in that even now around $40 \%$ of mineworkers in South Africa are Africans from outside South Africa (down from between 80 and $90 \%$ at times) (Crush 1995). Although this story provides a number of pointers to understanding the present situation ${ }^{3}$, it is not the whole picture.

Since 1994 (roughly), a new debate has begun about undocumented and documented immigrants and migrants, and their place in South African society. Against the background of signs of xenophobia in public discourse, it has become clear that police brutality and other forms of abuse of migrants by officialdom in South Africa are widespread and in some sectors, systematic (Human Rights Watch 1998).

A Draft Green Paper on International Migration was presented to the minister of Home Affairs Mr. Buthelezi in May last year ${ }^{4}$. The next stage would be the finalising of the Green Paper and after public scrutiny, the drafting of a White Paper forming the basis for a comprehensive new legal and administrative system.

The Draft Green Paper presents a very different position to the issue of foreign migrants and immigration than manifested in street confrontations and important sections of present officialdom. The Draft Green Paper is rights-based and tries to put forward a position in which regional solutions are sought. When read with statements and speeches made by a number of senior members of the Cabinet, all seems to bode well for the acceptance of a legal and administrative system regarding immigrants and migrants which will change the situation for the better. However, the process has dragged on somewhat and suspicions are that the possible political fallout of a rights-based legal framework for international migration plays an important role in the delay (Human Rights Watch 1998:6).

My intention is to add to existing attempts at understanding xenophobia in South Africa. In particular, the xenophobia relating to the fact that many other Africans want to make a living in South Africa is under scrutiny.

2. South Africa is not unique in Africa in having to deal with migrant and large population movements. Adepoju provides a concise overview of trends and issues (1995).

3. The history of migrant mine workers is complex. In a context of limited South African supply of labour in the mines, a network of recruiting offices in neighboring states and protectorates were instituted almost from the start by mining houses. For many years these 'foreign' migrants were not regarded as a threat to the interest of South African labour because the South African population resisted proletarisation as long as possible, because mining was rightly regarded as extremely dangerous work and because of the limits set by the apartheid state on housing families of migrant labour. However, the non-South African component of mine labour grew to be very important not only in numbers but also in that they have come to occupy a large majority of the more skilled jobs (Jeeves and Crush 1995). This development made the mines less dependent on South Africans and was to some extent based on the notion of particular ethnic groups being better suited for the work than others. But in a country where the colonial and apartheid intention to proletarise the African population to provide cheap and pliable labour was terribly successful, the migrants came to constitute a threat to the immediate interests of South African labour. This does not only relate to jobs but also to housing (Laburn-Peart 1995) and to control of women (Moodie \& Ndatshe 1995).

4. http://www.polity.org.za/govdocs/green_papers/migration/migrate.htm 


\section{Religion and culture and the reception of migrants}

What does religion and culture do in the context of migration reception? To set the scene, a brief account of tendencies and trends relating to religion and culture in public discourse will be provided.

\subsection{Religion and culture in public discourse}

Religion and culture were major aspects of the conflicts of the past. Colonial and apartheid history cannot be understood without reference to the various attempts by colonial and apartheid regimes to control religion and mould and delimit culture (see Chidester 1996). It also played a major part in the resistance and survival of African people in a context of oppression (see Comaroff 1985).

The legacy of this complex and contradictory story of religion and culture in South Africa is still with us. However, the new constitutional and political dispensations as well as the sometimes dramatic role of globalisation in South African society has changed the scene forever. Among other changes, the direct structural associations between religious institutions and particular reified cultural constructions and public institutions of the postapartheid society have slackened substantially. This will make it more difficult to define the role of religion and culture in post-apartheid South Africa (Müller 1997).

Presently, many look to religion and culture to provide a so-called 'moral' base to the development of a truly humane society. Religious leaders as well as President Nelson Mandela and Vice-President Thabo Mbeki expressed this tendency in recent speeches. When they speak of the quest for an 'African Renaissance', the fight against poverty and the need for recognition of the contribution of all, political and religious leaders specifically make mention of religion and of different 'cultural' groups. This trend is furthered by ignoring, avoiding, or denigrating the divisive and parochial possibilities also contained in religious and cultural symbolism in public discourses. Dominant themes in South African discourses relying explicitly on religious and cultural arguments can be typified as attempts to bring together rather than divide, to recognise rather than deny, to reconcile rather than to insulate. Some important public figures and symbols in recent times seem to fit this typology as icons. Nelson Mandela, Bishop Tutu, South African sport, the notion of the rainbow nation, the ubuntu notion, etc. are instances supporting the typology.

Contrary trends can also be identified and some have become quite visible. In the context of Islam in South Africa being more at home with pluralism that ever before (Moosa 1993), a new movement seems to be going in an opposite direction. The PAGAD movement (People against Gangsterism and Drugs) has become strongly associated with Islam in general and with radical and sectional interpretations of what being Muslim means in particular. However, an important aspect of PAGAD's attempts at gathering the support of the public for the cause has been to downplay a particular association with Islam and to deny relations to the clearly fundamentalist Qibla-group (Esack 1988:484-488) associated with Achmad Cassiem. PAGAD tries to project determination to resist crime and the commonality of that purpose, as well as general communal involvement, as the actual essential character of the movement. This avoids bucking the dominant tendency of employing cultural and religious arguments almost exclusively in discourses about unity, reconciliation, recognition, etc.

In a thorough study of elite perceptions, the opinions of persons in elite positions also bear out some of the tendencies described above. Contrary to expectations intimated in his study, Kotzé concludes that the potential for conflict in which opposing sides are defined in terms of religion and culture (when not defined in ethnic terms) are very limited. On the 
other hand, he does point to ethnic formations and constructions as possibly defining aspects of future conflicts among South Africans (Kotzé 1997). This has not been actualised in any significant manner yet.

Polls at the end of 1998 seem to indicate that the dominant discourse of the leading political party is holding ground (recent Markinor and HSRC-polls reported a slight increase in support for the ANC). Whether this is due to the arguments about religion and culture alone is dubious. Nevertheless, the ANC is not losing ground because of the very public commitment to an African renaissance, to reconciliation, to pluralism and to religious and cultural elements in the articulation of these notions.

This association of religion and culture with human rights and social concern and the development of recognition, reconciliation and unity as social values equally associated with religion and culture, has to be attributed to the process of coming to terms with the apartheid system and its colonial precursor.

\subsection{Xenophobia: paradox or predestined?}

Even if public discourses in South Africa tend to utilise religion and culture in a tolerant and pluralist expression of supposed common commitments, the stark realities of the South African landscape cannot be ignored. The social welfare projects undertaken by the government have not changed the basic realities of life in South Africa. A very basic interpretation of the reasons for tendencies of xenophobia would point to the estimated $40 \%$ plus unemployment, rising levels of crime, competition for trading space and housing and a very cramped informal business sector. Another issue would be the association of Nigerians with drug running, Malawians with AIDS and all sorts of generalisations like these.

It is probably to be expected that the success of politicians in winning elections and the success of religious leaders in keeping their following, does not translate directly in changing attitudes of the voters and followers in everyday life. It may therefore seem like a paradox if a country where foreigners are killed for being foreign have leaders who manifest great tolerance and openness when articulating their approach to this and related issues. However, this is only a paradox if one has not incorporated a very robust sense of the daily struggle for survival among a large proportion of South Africans. The competition for places in the job market is real, as is the competition for housing, for hawking space on a pavement, for the attention of a medical person, etc. When looking at these realities, xenophobia seems to be predestined.

However, the arguments of the researchers who have studied the economics and social trends of migrancy, go in a different direction. They point to myths concerning central features of the xenophobia which, they say, is added to by the media and certain political parties. A brief list of these myths include the idea that all the poor or otherwise desperate Africans would like to come to South Africa; that the majority of those who come, enter South Africa illegally; that they come to get jobs and social services; that they take jobs which otherwise would have gone to South Africans; etc. (McDonald, Zinyama, Gay \& de Vletter 1998; Reitzes 1997). These notions have all proved to be distortions or falsities. In contrast to these notions research has found that most migrants find significant circumstances (less crime, more land, morally less problematic, better housing) to be better at home; that the majority enter South Africa legally; that many visit family and friends and then go back, that they are quite willing to pay for services; that most who stay are selfemployed; etc. A study of small enterprises in Johannesburg has shown that the businesses run by immigrant entrepreneurs are actually creating jobs for South Africans and have all 
prospects of increasing their contribution to the South African economy in this way (Rogerson 1997).

\subsection{Religion and culture as pliable resources}

Why then the xenophobia? One has to be realistic and note that some migrants do come in illegally, that they do undercut South African wages in some instances and would probably be willing to work harder to keep these jobs, having taken more risk in getting them. If one adds the role of the media and particular political parties accused of deliberately 'fanning the flames of xenophobia' (Crush 1997), one might just have a fair answer to the reason for the signs of xenophobia in contemporary South Africa. However, two other aspects have to be taken into account. These are the logics of nationalism and of particularistic and exclusive interpretations of religion and culture.

The issue of nationalism cannot be dealt with directly. Suffice to say that nationalism is a long tradition in South African politics. Most of the major parties use some sort of nationalist rhetoric at times. Its role in creating xenophobia should be contemplated.

However, the role of religion and culture is at issue. Religion, approached as a 'cluster concept' relating to 'an open set of discursive, practical and social strategies of symbolic and material negotiation' (Chidester 1996: 259), has close affinity to culture in that culture is also a cluster concept of the same type. Both are affected deeply by the processes of globalisation and by modernity (Castells 1997; Beyer 1994; Comaroff \& Comaroff 1993).

Religion and culture may also be used in the opposite direction as that implied and articulated in the present dominant discourse of recognition, unity and reconciliation. There is no reason to suppose that religion or culture cannot be put to uses that contradict the dominant discourse as outlined above. Exactly because religion and culture are strategies of meaning and practice rather than timeless and fixed substances, religious or cultural arguments can be construed that portray foreigners as being inferior, less deserving of rights or humanity, reducible to a common negative, legitimately expendable. Religion and culture present themselves as resources for handling issues like poverty, crime, social insecurity, violence, etc. The way in which these resources are utilised does not just depend on public discourse at a national level.

However, this would not be much of a contribution to make if one left it at that level of generality. The impact of globalisation, of high modernity, of the technological revolution and the transformation of capitalism have brought about 'the widespread surge of powerful expressions of collective identity that challenge globalization and cosmopolitanism on behalf of cultural singularity and people's control over their lives and environment' (Castells 1997: 2). Included in the possibilities discussed by Castells are 'a whole array of reactive movements that build trenches of resistance on behalf of God, nation, ethnicity, family, locality, that is, the fundamental categories of millennial existence now threatened under... (Castells 1997:2). Others have also pointed to and explored the particular affinity between identities built on cultural and religious resources and globalisation (Robertson 1993: Beyer 1994).

In the case of xenophobia in South Africa, very little empirical study has been undertaken to establish all the reasons for it (Fontana 1997: 15). From the arguments of Castells and others, it seems imperative to investigate religion and culture as well.

A few pointers exist as to the possible role of culture and religion. The makwerekwere epithet used to denigrate foreigners is said to mock the sound of the languages used by foreigners. This is used not just as a collective term but also as a way of saying that the foreigner is a non-person. There is a cultural dimension to that in that South Africans 
currently take it for granted that all who are human must be treated as humans and are actually the means to one's own humanity. The ubuntu notion expresses this attitude and it is certainly part of the dominant discourse as outlined above. To deny foreigners their humanity is to deny that they are needed.

This argument becomes even less speculative and one-dimensional if one analyses the reports of evictions, abuse, and angry confrontations between foreigners from Africa and South African citizens. The list of those targeted does not, as a rule, include people from Lesotho, Botswana or Swaziland. Study of newspaper reports and available research data, did not refer to a single instance contradicting this trend. There may be many reasons for this but it is certainly worth considering the linguistic and cultural ties between these countries and South Africa. In all three cases, the national language is also one of the official South African languages. Even though many linguistic and cultural ties with Zimbabwe and Mozambique also exist, these are significantly more marginal than the others cited. The possibility of a somewhat ethnically and linguistically defined 'us' as opposed to a 'different' 'them' should be explored if a more complete understanding of the workings of xenophobia is to be gained ${ }^{5}$.

\section{Conclusion}

The fact that there seems to be sufficient reasons for South Africans to be xenophobic was somewhat complicated by the exposure of all sorts of myths by researchers intent on educating the public and supporting efforts to develop a more equitable and human approach to migrants and immigrants to South Africa. Their arguments and figures may yet carry the day in the process of the drafting of a legal and administrative framework based on human rights and a regional approach to the issue of migration. However, they may have fallen prey to an illusion often held. Religion and culture are not static and do not even exist as substantial entities. They do however provide a window on strategies of meaning and practice not gained by other means of social inquiry. Indications are that very little attempt has so far been made to investigate the role of religion and culture in the abuse and denigration of migrants and immigrants to South Africa. This has to be rectified if a lasting solution is to be found. It is already against the law to throw somebody out of a train. This did not stop an angry crowd on 4 September 1998.

5. Other possibilities to be explored could include denominational religious differences possibly exacerbated by linguistic differences. Although denominational differences within African communities are important, these have not recently been to focus of confrontations of any significance. This kind of 'difference' was imported by missionaries. Indians do, however, sometimes feature on the lists of those hawker organisations want to exclude. 


\section{BIBLIOGRAPHY}

Adepoju A 1995. 'Emigration dynamics in sub-Saharan Africa', in: International Migration, 33 (4/3).

Beyer P 1994. Religion and globalisation. London: Sage.

Castells M 1997. The Power of Identity. Oxford: Blackwell.

Chidester D 1996. Savage systems. Charlottesville: University Press of Virginia.

Comaroff J 1985. Body of power, spirit of resistance: the culture and history of a South African people. Chicago: Chicago University Press.

Comaroff J \& Comaroff J 1993. Introduction', in: Comaroff J \& Comaroff J (eds.) Modernity and its malcontents. Chicago: University of Chicago Press.

Crush J 1995. 'Mine migrancy in the contemporary era', in: Crush J \& James W (eds.), Crossing Boundaries. Cape Town: IDASA.

Crush J, Jeeves A \& Yudelman D (eds.) 1991. South Africa's labor empire. Cape Town: David Phillip.

Esack F 1988. Three Islamic strands in the South African struggle for justice', in: Third World Quarterly, 10 (2), 478-498.

Fontana B 1997. The state of migration research in South Africa. Foundation for Global Dialogue Occasional Paper, no. 8. Johannesburg: Foundation for Global Dialogue.

Human Rights Watch 1998. 'Prohibited Persons'. Abuse of undocumented migrants, asylum seekers, and refugees in South Africa. New York: Human Rights Watch.

Jeeves A \& Crush J 1995. 'The failure of stabilisation experiments on South African gold mines', in:, Crush J \& James W (eds.), Crossing Boundaries. Cape Town: IDASA.

Kotzé HJ 1997. Culture,Ethnicity and Religion: South African Perceptions of Identity. Occasional paper of Adenauer Foundation. April 1997, Johannesburg.

Laburn-Peart C 1995. 'Housing as a locus of power', in: Crush J \& James W (eds.), Crossing Boundaries. Cape Town: IDASA.

McDonald D, Zinyama L, Gay J \& de Vletter F 1998. Challenging xenophobia: myths and realities if cross-border migration in Southern Africa. Migration Policy Series no. 7.

Moodie D \& Ndatshe V 1995. 'Town women and country women: housing preferences at Vaal Reefs Mine', in: Crush J \& James W (eds.), Crossing Boundaries. Cape Town: IDASA.

Moosa E 1993. 'Discursive voices of Diaspora Islam in Southern Africa', in: Jurnal Antropologi dan Sosiologi, 20, 29-60.

Müller HP 1997. Religion as system, performance and stock of knowledge: towards an appropriate social-theoretical perspective on the societal significance of religion in South Africa. Unpublished D.Phil. dissertation, University of Stellenbosch.

Reitzes M 1997. Undocumented migration: dimensions and dilemmas. Paper prepared for Green Paper Task Group on International Migration, March 1997.

Robertson R 1993. 'Community, Society, Globality, and the category of Religion', in: Barker E, Beckford JA \& Dobbelaere K (eds.) Secularisation, Rationalism and Sectarianism. Oxford: Clarendon.

Rogerson CM 1997. International migration, immigrant entrepreneurs and South Africa's small enterprise economy. Migration Policy Series no. 3.

Wilson F \& Ramphele M 1989. Uprooting poverty. Cape Town: David Phillip. 